Review

\title{
Current research, regulation, risk, analytical methods and monitoring results for nicarbazin in chicken meat: A perspective review
}

\author{
Danniele Miranda Bacila ${ }^{\mathrm{a}}$, Vivian Feddern ${ }^{\mathrm{b}, *}$, Luciana Igarashi Mafra ${ }^{\mathrm{a}}$, \\ Gerson Neudí Scheuermann ${ }^{\mathrm{b}}$, Luciano Molognoni ${ }^{\mathrm{c}}$, Heitor Daguer ${ }^{\mathrm{c}}$ \\ a Universidade Federal do Paraná, Av. Coronel Francisco Heráclito dos Santos, 210, 81531-970 Curitiba, PR, Brazil \\ b Embrapa Suínos e Aves, BR 153, km 110, 89715-899 Concórdia, SC, Brazil \\ c Ministério da Agricultura, Pecuária e Abastecimento, Laboratório Nacional Agropecuário (Lanagro/RS), Rua João Grumiché, 117, 88102-699 São José, SC, Brazil
}

\section{A R T I C L E I N F O}

\section{Keywords:}

Food safety

DNC

Maximum residue limit

LC-MS/MS

Immunoassay

Litter reuse

\begin{abstract}
A B S T R A C T
This review presents up-to-date information about current research on nicarbazin, one of the most used anticoccidials in poultry production. The focus is to elucidate regulation concerning nicarbazin, limits for its residues in food, how maximum residue limits in different countries are calculated regarding edible chicken tissues and the possible implications in human health. Analytical methods to extract and quantify this residue, expressed as dinitrocarbanilide (DNC) are presented and discussed, including qualitative screening and quantitative/confirmatory analytical methods. Monitoring results and occurrence of DNC residues in chicken meat are discussed. Additionally, the causes of eventual chicken meat contamination and possible solutions to reduce or eliminate DNC residue in tissues are also presented. The paper concludes with perspectives, the current state of DNC residue analysis and suggestions for future research, especially considering the gap in the study of residue recycling effect due to continuous chicken litter use.
\end{abstract}

\section{Introduction}

Chicken meat has a great nutritional value and is recognized as a healthy and low-cost source of animal protein, which makes it accessible to low-income families worldwide. While the United States is positioned as the world's leader in poultry production, Brazil is the leading broiler meat exporter in international trade (ABPA, 2016; USERS, 2016). One important issue in this meat market is related to food safety, especially concerning chemical residues in the final products. This relates to nicarbazin, a product of chemical synthesis widely used in commercial intensive broiler farming to control the coccidiosis.

Coccidiosis refers to a disease caused by protozoa of the Eimeria genus promoting a wide range of injuries in poultry intestines. Parasites compromise the nutrient absorption and feed conversion, affecting poultry weight gain or even causing mortality, as a consequence of intestine damage (Blake \& Tomley, 2014; Chapman, 2014). The extent of losses caused by Eimeria spp. in poultry flocks was relieved with the advent of anticoccidials in the 1950s. Nicarbazin, one of the first anticoccidials developed, is still being used successfully in prophylactic programs. However, considering recent concerns with undesirable levels of residues of this feed additive in chicken products intended for human consumption, the aim of this article is to contribute to the understanding about safety related to nicarbazin residues (expressed as DNC) in chicken tissues, considering important common questions of any consumer: What would be the possible effect of DNC residues on humans after consumption of contaminated food? How are the acceptable residue levels calculated in major chicken producing and consuming countries, notably, the US, Brazil, and the European Union? How is nicarbazin used in poultry production, and what are safety measures concerning the residue in the final products? Which analytical methods have been employed to quantify DNC residues in foods? Which strategies/researches regarding

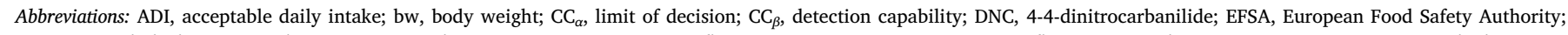

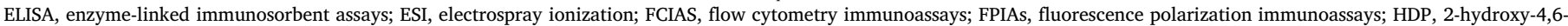

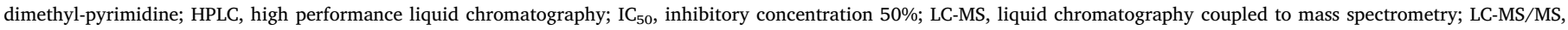

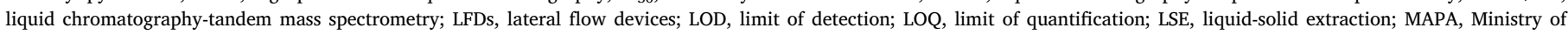

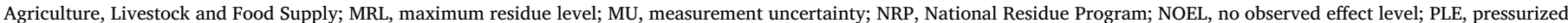

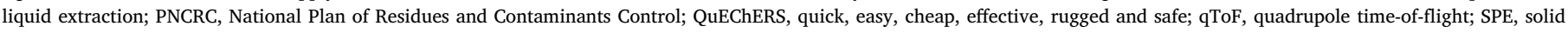
phase extraction; SPR, surface plasmon resonance; UHPLC, ultra high performance liquid chromatography

* Corresponding author.

E-mail address: vivian.feddern@embrapa.br (V. Feddern). 
the use of nicarbazin can be applied to improve food safety? What does the data show about DNC residue in edible chicken tissues?

\section{Nicarbazin}

The chemical substances that act specifically in preventing and combating coccidiosis are known as anticoccidials, which are classified according to the mode of action into coccidiostat (inhibit Eimeria growth) and coccidicide (promote life cycle interruption and parasite destruction). The use of anticoccidials is necessary to maintain health, animal welfare and suitable feed conversion, consequently avoiding broiler poor growth and mortality. Based on their origin, anticoccidials are classified as synthetic (nicarbazin, diclazuril, robenidine, clopidol, and halofuginone) or ionophores (narasin, lasalocid, monensin, maduramicin, senduramicin, and salinomycin). While synthetic anticoccidials are manufactured through chemical reactions, ionophores are produced by different bacteria of the Streptomycetaceae family (Clarke et al., 2014). These products are commercially available and may be employed at different stages of the poultry life cycle, either alone or combined (Clarke et al., 2014; Spínosa, Palermo-Neto, \& Górniak, 2014). Nicarbazin, an anticoccidial synthesized in 1955, is still one of the most efficient products used in broiler chicken feed by the largest broiler meat producers and exporters worldwide.

It consists of an equimolar complex (Fig. 1) which undergoes fast in vivo dissociation into two substances: 4-4-dinitrocarbanilide (DNC) and 2-hydroxy-4,6-dimethyl-pyrimidine (HDP). The active component is DNC (solubility in water is lower than $0.02 \mathrm{mg} / \mathrm{L}$ ) while HDP (hydrophilic) increases DNC absorption. The effectiveness of the complex is higher than DNC used alone. Nicarbazin presents an effective anticoccidial activity, acting as either coccidiostat or coccidicide (Berchieri Júnior, Silva, Fábio, Sesti, \& Zuanaze, 2009; EFSA, 2003), promoting adequate coccidiosis control. No resistance incidences that could compromise coccidiosis control have been reported so far (EFSA, 2003; Rogers et al., 1983; Spínosa et al., 2014). Thus, this compound is still widely used in poultry industry (Chapman, 2014).

Regarding the use of anticoccidials, the main safety measures to assure food safety in poultry production are to follow the regulated dosages and recommended withdrawal periods. In Brazil, the use of nicarbazin in broiler feed is regulated by the Ministry of Agriculture, Livestock and Food Supply (MAPA). A maximum concentration of $125 \mathrm{mg} / \mathrm{kg}$ nicarbazin of this product is allowed in feed, with a withdrawal period of 10 days before slaughter (MAPA, 2015c; Poli-Nutri, 2016). In the European Union, the maximum amount of nicarbazin in feed is the same as Brazil, but the minimum withdrawal period is one day (EC, 2010a). Meanwhile, in the USA, the amount of nicarbazin authorized in feed is up to $181.6 \mathrm{mg} / \mathrm{kg}$, with a withdrawal period of 4-5 days (GPO, 2012).

When nicarbazin is co-administered with other anticoccidials, there are specific rules regarding to dosage and withdrawal period in different countries. Brazil allows nicarbazin association with maduramicin (40:3.75), monensin (40:40 to 50:50), narasin (40:40 to 50:50) or senduramicin (40:15 to $48: 18$ ) in the mentioned concentrations $(\mathrm{mg} / \mathrm{kg}$ ) (Biofarma, 2016; Elanco, 2016; Huvepharma, 2016; Phibro, 2016). In the EU, only narasin is allowed to be associated in a dosage of $40: 40$ to $50: 50 \mathrm{mg} / \mathrm{kg}$ (EC, 2010a, $2010 \mathrm{~b})$, as it is in the USA at $27: 27$ to $45: 45 \mathrm{mg} / \mathrm{kg}$ (GPO, 2012).

\subsection{Toxicity}

Toxic reactions generated by anticoccidials may occur in different species of animals, including broilers, depending on the administration levels (U.S. National Library of Medicine, 2013). Nicarbazin levels above $125 \mathrm{mg} / \mathrm{kg}$ may lead to poultry poisoning, mainly affecting the thermoregulatory mechanisms. Therefore, the use of nicarbazin is generally limited to the initial growing phase, since it may increase heat stress effects in later periods, leading to mortality (Spínosa et al., 2014).

A no observed effect level (NOEL) is defined as the higher level of exposure of an organism, at which no statistically significant adverse effect occurs in the exposed population (EFSA, 2003, 2010a). The concentration of $240 \mathrm{mg} / \mathrm{kg}_{\mathrm{bw}}$ of nicarbazin a day was established by Joint FAO/WHO Expert Committee on Food Additives (JECFA, 1999), while EFSA (2010a) proposed 154 and $51 \mathrm{mg} / \mathrm{kg}_{\mathrm{bw}}$ of DNC and HDP, respectively, based on chronic toxicity studies in rats and dogs. The observed effects were weight loss and changes in organs such as kidney and liver (EFSA, 2010a).

Developmental toxicity studies in rats showed maternal weight loss and fetus abnormalities at the highest nicarbazin concentration. Therefore, a NOEL of $200 \mathrm{mg} / \mathrm{kg}_{\mathrm{bw}}$ a day for maternal and fetal toxicity was established (JECFA, 1999).

Regarding mutagenicity, nicarbazin presented genotoxicity for Salmonella spp. However, in vivo tests with mammals did not confirm this effect and nicarbazin was considered genotoxic risk-free. An impurity resulting from DNC synthesis is $p$-nitroaniline, which should be below $0.1 \%$ in nicarbazin, based on genotoxicity and carcinogenicity assessments (EC, 2010a; EFSA, 2010a).

The European Food Safety Authority (EFSA) claims that nicarbazin has low acute toxicity (EFSA, 2010a). In fact, in humans acute toxicity has not been reported so far, but there is concern over chronic toxicity when people are subjected to low levels of the anticoccidial during long-term exposure. Many countries are implementing surveillance programs to monitor and prevent unacceptable contamination with anticoccidial residues in animal products intended for human consumption (Clarke et al., 2014).

\subsection{Acceptable daily intake}

Toxicological information has been serving as a basis for the establishment of the acceptable daily intake (ADI) for humans. ADI is derived from NOEL with the application of an uncertainty factor. Then, the maximum residue levels (MRLs) have been established for foods of animal origin, in order to follow ADI and to avoid risks to consumer (Dorne et al., 2013).

Nicarbazin ADI was established based on a NOEL value of $200 \mathrm{mg}$ / $\mathrm{kg}_{\mathrm{bw}} /$ day, obtained from the development toxicity evaluation in rats and from a safety factor of 500 (high due to limitations of the available data). Therefore, a calculated nicarbazin ADI of $0.4 \mathrm{mg} / \mathrm{kg}_{\mathrm{bw}}$ has been established by Codex Alimentarius (FAO/WHO, 2015; JECFA, 1999), as presented in Table 1. According to this report, it has been assumed that nicarbazin at $0.4 \mathrm{mg} / \mathrm{kg}_{\mathrm{bw}}$ corresponds to $24 \mathrm{mg}$ of DNC for a $60 \mathrm{~kg}$ person, although NOEL was obtained in terms of nicarbazin, not DNC. Alternatively, European Union considers DNC instead of nicarbazin and has adopted $0.77 \mathrm{mg} \mathrm{DNC} / \mathrm{kg}_{\mathrm{bw}}$ as ADI (corresponds to $46 \mathrm{mg}$ of DNC,

$$
\text { DNC }
$$<smiles>O=C(Nc1ccc([N+](=O)[O-])cc1)Nc1ccc([N+](=O)[O-])cc1</smiles>

HDP<smiles>Cc1cc(C)nc(O)n1</smiles>

Fig. 1. Structural formula of the nicarbazin equimolar complex (DNC plus HDP).

Source: Tarbin et al. (2005). 
Table 1

Toxicological information used to obtain nicarbazin/DNC acceptable daily intake.

Source: adapted from Dorne et al. (2013), EFSA (2010a), FAO/WHO (2015), and JECFA (1999).

\begin{tabular}{|c|c|c|c|c|c|}
\hline Compound & $\begin{array}{l}\text { NOEL } \\
\left(\mathrm{mg} / \mathrm{kg}_{\mathrm{bw}} /\right. \\
\text { day) }\end{array}$ & Observed effect & Species/study & Uncertainty factor & $\begin{array}{l}\text { ADI } \\
(\mathrm{mg} / \\
\left.\mathrm{kg}_{\text {bw }}\right)\end{array}$ \\
\hline Nicarbazin & 200 & $\begin{array}{l}\text { Maternal toxicity (mortality and low bodyweight gain) and fetal } \\
\text { abnormalities (low bodyweight and delayed ossification) }\end{array}$ & $\begin{array}{l}\text { Rats/developmental } \\
\text { toxicity }\end{array}$ & 500 & 0.40 \\
\hline $\begin{array}{l}\text { DNC (marker residue of } \\
\text { nicarbazin) }\end{array}$ & 154 & Increase of serum alanine aminotransferase & $\begin{array}{l}\text { Dogs/chronic feeding } \\
\text { ( } 2 \text { years) }\end{array}$ & 200 & 0.77 \\
\hline
\end{tabular}

considering a $60 \mathrm{~kg}$ person). The ADI of $0.77 \mathrm{mg} \mathrm{DNC} / \mathrm{kg}_{\mathrm{bw}}$ refers to a previously mentioned study considering NOEL of $154 \mathrm{mg} / \mathrm{kg}$ (Table 1 ). According to EFSA, ADI recommendation should be calculated based on DNC, because the consumer will be exposed to this compound, not to nicarbazin complex (DNC and HDP) (EFSA, 2010a). In the USA, as in Brazil, no ADI for nicarbazin has been published yet (GPO, 2012; MAPA, 2015c). Since both countries are signatories to Codex, the ADI of $0.4 \mathrm{mg} / \mathrm{kg}_{\mathrm{bw}}$ should be set as a reference.

\subsection{Maximum residue limits in broiler tissues}

The use of certain products in poultry production can cause residue deposition in meat. To avoid risks to consumer's health and exceeding the recommended ADI, authorities have been restricting the use of specific veterinary drugs on the prevention and treatment of livestock diseases, and assigned MRLs of these products in food (Pizarro \& Ferreira, 2014).

The MRLs are calculated considering daily consumer exposition to nicarbazin, expressed as its marker residue (DNC), regarding the most consumed chicken tissues. The current MRLs for edible chicken tissues established by FAO/WHO and followed by regulatory agencies of Brazil, Europe and United States are presented in Table 2. The Joint FAO/WHO Expert Committee on Food Additives has recommended through the Codex Alimentarius (FAO/WHO, 2015) the MRL of $200 \mu \mathrm{g}$ of $\mathrm{DNC} / \mathrm{kg}$ in all broiler tissues, based on estimates presented in Table 3. Brazilian regulation follows Codex Alimentarius upper limit $(\mathrm{MRL}=200 \mu \mathrm{g} / \mathrm{kg}$ ), but considers only muscle tissue (MAPA, 2015a, 2015b). In the European Union, DNC MRLs used to be the same as Codex Alimentarius, but in August 2010 the values were changed to 15, 6 , 4 and $4 \mathrm{mg} / \mathrm{kg}$ for liver, kidney, muscle and skin/fat, respectively, through the Commission Regulation 875, as expressed in Table 2 (EC, 2010a). In the United States, the Code of Federal Regulations has settled only one nicarbazin MRL ( $4 \mathrm{mg} / \mathrm{kg}$ ) for different broiler tissues (GPO, 2012), however it is not informed if these results refer to DNC. When evaluating the MRLs of different countries considered in this survey, only Brazil follows the DNC limits recommended by the Codex Alimentarius (FAO/WHO, 2015). Since those are the strictest limits available, a wider food safety margin may be provided to meat consumers.

Table 2

Maximum residue limits (MRLs) of nicarbazin active substance (DNC) in chicken tissues ( $\mu \mathrm{g} / \mathrm{kg})$.

Source: EFSA (2010a), FAO/WHO (2015), GPO (2012), and MAPA (2015b).

\begin{tabular}{lllll}
\hline Tissue & \multicolumn{2}{l}{ DNC $(\mu \mathrm{g} / \mathrm{kg})$} & & \\
\cline { 2 - 5 } & $\begin{array}{l}\text { Codex }(\mathrm{FAO} / \\
\text { WHO) }\end{array}$ & Brazil & USA & European Union \\
& 200 & & & \\
\hline Muscle & 200 & 200 & 4000 & 4000 \\
Liver & 200 & - & 4000 & 15,000 \\
Kidney & 200 & - & 4000 & 6000 \\
Skin/fat & $0-400$ & - & 4000 & 4000 \\
$\begin{array}{c}\text { Average daily intake }(\mu \mathrm{g} / \\
\text { kg }\end{array}$ & & - & 770 \\
\hline bw) & & & & \\
\hline
\end{tabular}

FAO/WHO estimates that muscle may have $308 \mu \mathrm{g}$ of nicarbazin total residue in $1 \mathrm{~kg}$ of tissue (Table 3 ). Considering a daily consumption of $300 \mathrm{~g}$ of muscle, it leads to a maximum DNC daily intake of $92 \mu$ g. Adding the total residue values in liver $(44 \mu \mathrm{g})$, kidney $(67 \mu \mathrm{g})$ and skin/fat $(11 \mu \mathrm{g})$ to that quantity, it accounts for $214 \mu \mathrm{g}$, as the theoretical maximum daily intake of DNC, what means the consumer exposition to this residue. Reminding the ADI of $0.4 \mathrm{mg} /$ $\mathrm{kg}_{\mathrm{bw}}$ obtained from toxicological studies (Table 1) and considering a person of $60 \mathrm{~kg}$, the acceptable nicarbazin ingestion, as DNC, is $24,000 \mu \mathrm{g}\left(60 \mathrm{~kg} \times 0.4 \mathrm{mg}_{\text {nicarbazin }} / \mathrm{kg}_{\mathrm{bw}}=24 \mathrm{mg}\right)$. Therefore, the calculated MRL of $214 \mu \mathrm{g}$, in Table 3, corresponds to $0.9 \%$ of the ADI $(214 \mu \mathrm{g} / 24,000 \mu \mathrm{g})$, showing a wide safety margin to the adopted MRLs ( $200 \mu \mathrm{g}$ DNC/kg tissue). These DNC MRLs were generated by multiplying the estimation of total residues in tissues by the percentage of marker residue $(444 \times 0.45 ; 1333 \times 0.15 ; 308 \times 0.65$; $222 \times 0.90 \approx 200 \mu \mathrm{g}$ DNC/kg tissue).

The regulatory agency of the European Union (EFSA) calculates the MRLs similarly, but with differences on the data source. Firstly, the daily intake of total residue considered the estimate of total residue in chicken tissues, obtained from a broiler experiment with Koffogran $^{\circledast}$ at $125 \mathrm{mg} / \mathrm{kg}$ nicarbazin. Another difference relies on the marker residue ratios among tissues. The ratio between the marker residue (DNC) and the total residues, utilized by FAO/WHO account for $90 \%$ in skin/fat, $65 \%$ in muscle, $45 \%$ in liver and $15 \%$ in kidney; while in the case of EFSA, the amounts are $40 \%, 20 \%, 40 \%$ and $30 \%$, respectively (Table 3 ). These ratios are quite different, because FAO/ WHO data considered the association of nicarbazin to an ionophore, while the EFSA considered data from broilers fed with nicarbazin only. It is known that nicarbazin association to ionophores results in higher level of residues (EFSA, 2010b). It may explain the difference in residue deposition of DNC in muscle among FAO/WHO (65\%) and the EFSA (20\%). Other issue refers to the proportion among consumed tissues. Even though both regulatory agencies (FAO vs. EFSA) assume the same total consumption ( $500 \mathrm{~g} /$ day), kidney $(50 \mathrm{~g} /$ day vs. $10 \mathrm{~g} /$ day) and skin/fat (50 g/day vs. $90 \mathrm{~g} /$ day) show different amounts (Table 3 ). Thus, the sum of the theoretical maximum daily intake of residue per tissue differs between these agencies (214 vs. $10,850 \mu \mathrm{g})$. Although the value settled by the EFSA was much higher than the FAO/WHO one, it corresponds to only $24 \%$ of the European recommended ADI (up to $770 \mu \mathrm{g} / \mathrm{kg}_{\mathrm{bw}} /$ day).

\section{Analytical methods to quantify nicarbazin active substance (DNC)}

In order to determine anticoccidials in animal-origin products, qualitative methods may be used before residue quantification. In foods, routine analyses which are quick, reliable and cheap are still a challenge. Sample preparation and extraction procedures are timeconsuming and must be optimized to meet exportation criteria and industry demand. The most commonly used methods for DNC quantification in chicken tissues, eggs and feed are summarized in Table 4. 
Table 3

Recommendation of DNC maximum residue limits for edible tissues from broilers and maximum daily intake recommended by FAO/WHO and EFSA. Source: EFSA (2010a) and JECFA (1999).

\begin{tabular}{|c|c|c|c|c|c|}
\hline & Liver & Kidney & Muscle & Skin/fat & Sum \\
\hline \multicolumn{6}{|l|}{$\mathrm{FAO} / \mathrm{WHO}$} \\
\hline Recommended MRL per tissue $(\mu \mathrm{g} / \mathrm{kg})$ & 200 & 200 & 200 & 200 & \\
\hline Ratio marker residue versus total residue (\%) & 45 & 15 & 65 & 90 & \\
\hline Estimate of total residue in tissue $(\mu \mathrm{g} / \mathrm{kg})$ & 444 & 1333 & 308 & 222 & \\
\hline Tissue consumption (g/day) & 100 & 50 & 300 & 50 & 500 \\
\hline Theoretical maximum daily intake of total residue per $\mathrm{kg}$ tissue $(\mu \mathrm{g})$ & 44 & 67 & 92 & 11 & 214 \\
\hline Consumption $(\% \mathrm{ADI})$ & & & & & 0.9 \\
\hline \multicolumn{6}{|l|}{ EFSA } \\
\hline Recommended MRL per tissue $(\mu \mathrm{g} / \mathrm{kg})$ & 15,000 & 6000 & 4000 & 4000 & \\
\hline Ratio marker residue versus total residue (\%) & 40 & 30 & 20 & 40 & \\
\hline Estimate of total residue in tissue $(\mu \mathrm{g} / \mathrm{kg})$ & 37,500 & 20,000 & 20,000 & 10,000 & \\
\hline Tissue consumption (g/day) & 100 & 10 & 300 & 90 & 500 \\
\hline Theoretical maximum daily intake of total residue per $\mathrm{kg}$ tissue $(\mu \mathrm{g})$ & 3750 & 200 & 6000 & 900 & 10,850 \\
\hline Consumption $(\% \mathrm{ADI})$ & & & & & 24 \\
\hline
\end{tabular}

\subsection{Extraction methods}

The diversity of food matrices and the physicochemical properties of veterinary drugs turn the development of analytical methods into a difficult task, especially from the sample preparation point of view. Various approaches to extract veterinary drugs have been applied to food and feed. Solid-liquid extraction with low temperature partitioning (Matus \& Boison, 2016), liquid-liquid extraction (Wang et al., 2014), QuEChERS (quick, easy, cheap, effective, rugged and safe), with or without modifications (Gressler et al., 2016; Guo et al., 2016; Huertas-Pérez et al., 2016), solid phase extraction (SPE) (Casado, Morante-Zarcero, Pérez-Quintanilla, \& Sierra, 2016), pressurized liquid extraction (PLE) (Boscher, Guignard, Pellet, Hoffmann, \& Bohn, 2010), and matrix solid-phase dispersion (Barker, 2007) have been satisfactorily adopted. Liquid-liquid and solid-phase extractions are the most suitable techniques applied for anticoccidial residues (Clarke et al., 2014; Wang et al., 2014). The choice of extraction method should fit for purpose. Monitoring and control tools that are routinely executed must be practical, economical, reproducible and, above all, reliable.

In this context, organic solvents, such as methanol and acetonitrile, are most commonly used to extract veterinary drug residues from biological samples. However, while these solvents are often capable of extracting all anticoccidials of interest, they also extract potential interferents from the matrix (Cronly et al., 2011; Huet, BienenmannPloum, Vincent, \& Delahaut, 2013). In these cases, SPE and QuEChERS have been employed to remove interferents, improving method selectivity and specificity. On the other hand, the clean-up by freezing (partition at low temperature) has been increasingly used. Like the dispersive SPE and QuEChERS, this procedure removes from matrix many endogenous components, presenting advantages due to their cost and practicality (Matus \& Boison, 2016). A study conducted by Coleman et al. (2014) entitled "Determination and Confirmation of Nicarbazin in Chicken Tissues" awarded the First Action Official Method status by the Expert Review Panel for Veterinary Drug Residues in May 2013. DNC has been successfully extracted with acetonitrile from chicken muscle and eggs, which are high in protein, followed by clean-up and centrifugation in order to precipitate protein. This procedure is fast and effective and may be used as a control and monitoring tool. This approach has been adopted by AOAC to determine DNC in foods.

\subsection{Analytical methods}

Anticoccidials have been detected in products of animal origin by rapid qualitative screening methods, which can be useful and less costly tools compared to other quantitative techniques. Enzyme-linked immunosorbent assays (ELISA), lateral flow devices (LFDs), fluorescence polarization immunoassays (FPIAs), biosensor assays, and more recently, flow cytometry immunoassays (FCIAs) have been applied for the detection of anticoccidials, before using confirmatory and quantitative methods as LC-MS (Huet et al., 2013; Li et al., 2017).

Antibodies are the main analytes of immunoassays. However, chemical coccidiostats, such as nicarbazin, may hinder the production of antibodies by the host. Low molecular weight compounds such as these types of feed additives, are bound to large carrier proteins. Thus, the immune reaction is not enough to form antibodies in the host, and this binding interaction process may affect both sensitivity and specificity of the resultant molecule (Clarke et al., 2014). The absence of functional groups or other structural properties implicated in the use of mimics or the production of chemical derivatives to permit immunogen preparation (Clarke et al., 2014; Li et al., 2017). These limitations can be overcome through the use of complementary techniques. However, these procedures may make the test more expensive, making its viability questionable in relation to the use of other analytical techniques.

The most cited immunoassay methods reported in poultry products for the detection of coccidiostats are ELISA (Beier, Ripley, Young, \& Kaiser, 2001; Connolly, Fodey, Crooks, Delahaut, \& Elliott, 2002; Huet et al., 2005) and surface plasmon resonance (SPR) biosensor (McCarney, Traynor, Fodey, Crooks, \& Elliott, 2003). Beier, Ripley, Young, and Kaiser (2001) used p-nitrosuccinanilic acid to mimic DNC, in order to produce monoclonal antibodies that bound DNC; LOD was set to $100 \mathrm{ng} / \mathrm{mL}$ in an indirect ELISA. Connolly, Fodey, Crooks, Delahaut, and Elliott (2002) used the same approach, but compared three different mimics to prepare immunogens and enzyme labels. The analytical parameter of the method was $\mathrm{IC}_{50}$, which can be defined as the drug concentration required for $50 \%$ in vitro inhibition. They found that two of the mimics ( $N$-succinyl-L-alanyl-Lalanyl-L-alanine-4-nitroanilide and $p$-nitrosuccinanilic acid) created the best immune responses and that a heterologous ELISA performed best for most of the resultant antibodies. The methods for antibody production and sample extraction were used by Huet et al. (2005) who developed an ELISA for the detection of DNC and halofuginone residues in poultry egg and muscle. Another research group (Mortier, Huet, et al., 2005) compared ELISA and LC-MS/MS regarding five anticoccidial residues in eggs, while Mortier, Daeseleire, and Van Peteghem et al. (2005) validated LCMS/MS in eggs and feed.

Since most chemical coccidiostats have a native chromophore cluster, UV detectors coupled to high performance liquid chromatography (HPLC) systems have been widely used for their quantitation (Kanda et al., 2003; Souza et al., 2001). Some methods for determination of nicarbazin as dinitrocarbanilide (DNC) were then developed, being able to measure DNC residues in the range of $15 \mu \mathrm{g} / \mathrm{kg}$ in eggs and tissues (Capurro, Danaher, Anastasio, Cortesi, \& O'Keeffe, 2005; Kanda et al., 2003). Fluorescence, a more selective technique than UV, has not been very used for the analysis of chemical coccidiostats, 
Table 4

Methods for DNC analysis in chicken tissues, eggs, feed and litter.

\begin{tabular}{|c|c|c|c|c|c|c|}
\hline $\begin{array}{l}\text { Analytical } \\
\text { techniques }\end{array}$ & Matrices & $\begin{array}{l}\text { Number of } \\
\text { analytes }\end{array}$ & Sample preparation & Sensitivity & $\begin{array}{l}\text { Recovery rates } \\
(\%)\end{array}$ & Reference \\
\hline ELISA & NA & 1 & NA & LOD: $100 \mathrm{ng} / \mathrm{mL}$ & - & $\begin{array}{l}\text { Beier, Ripley, Young, and Kaiser } \\
\text { (2001) }\end{array}$ \\
\hline ELISA & NA & 1 & NA & $\mathrm{IC}_{50}: 2.3-7.6 \mathrm{ng} / \mathrm{mL}$ & - & $\begin{array}{l}\text { Connolly, Fodey, Crooks, Delahaut, } \\
\text { and Elliott (2002) }\end{array}$ \\
\hline ELISA & $\begin{array}{l}\text { Egg } \\
\text { Muscle }\end{array}$ & 2 & NA & $\begin{array}{l}\mathrm{CC}_{\beta}:<10 \mu \mathrm{g} / \mathrm{kg} \text { in } \\
\text { muscle } \\
\mathrm{CC}_{\beta}:<3 \mu \mathrm{g} / \mathrm{kg} \text { in } \\
\text { eggs }\end{array}$ & $\begin{array}{l}85.0 \text { for muscle } \\
67.0 \text { for eggs }\end{array}$ & Huet et al. (2005) \\
\hline LC & $\begin{array}{l}\text { Eggs } \\
\text { Feed } \\
\text { Muscle }\end{array}$ & 1 & Supercritical fluid extraction (SFE) & LOQ: $400 \mu \mathrm{g} / \mathrm{kg}$ & $>98.0$ & Matabudul, Crosby, and Sumar (1999) \\
\hline LC & Feed & 1 & LSE (acetonitrile); purification (alumina) & $\begin{array}{l}\text { LOD: } 50 \mu \mathrm{g} / \mathrm{kg} \\
\text { LOQ: } 100 \mu \mathrm{g} / \mathrm{kg}\end{array}$ & $98.3-111.0$ & $\begin{array}{l}\text { Protasiuk, Olejnik, Szprengier- } \\
\text { Juszkiewicz, Jedziniak, and Zmudzki } \\
\text { (2015) }\end{array}$ \\
\hline LC & $\begin{array}{l}\text { Fat } \\
\text { Liver } \\
\text { Muscle }\end{array}$ & 2 & $\begin{array}{l}n \text {-Hexane defatting; LSE (acetonitrile); } \\
\text { Liquid-liquid partitioning }\end{array}$ & LOQ: $4 \mu \mathrm{g} / \mathrm{kg}$ & $>87.3$ & Kanda et al. (2003) \\
\hline LC & Muscle & 3 & LSE (acetonitrile); SPE (silica and C18) & $\begin{array}{l}\text { LOD and LOQ: } \\
5000 \mu \mathrm{g} / \mathrm{kg}\end{array}$ & $40.2-95.6$ & Souza et al. (2001) \\
\hline LC & Liver & 1 & $\begin{array}{l}n \text {-Hexane defatting; LSE (acetonitrile); } \\
\text { SPE (silica and C18) }\end{array}$ & $\begin{array}{l}\mathrm{CC}_{\alpha}: 228 \mu \mathrm{g} / \mathrm{kg} \\
\mathrm{CC}_{\beta}: 266 \mu \mathrm{g} / \mathrm{kg}\end{array}$ & $>70.0$ & $\begin{array}{l}\text { Capurro, Danaher, Anastasio, Cortesi, } \\
\text { and O'Keeffe (2005) }\end{array}$ \\
\hline LC-MS & $\begin{array}{l}\text { Egg } \\
\text { Muscle }\end{array}$ & 9 & LSE (acetonitrile) & $\begin{array}{l}\mathrm{CC}_{\alpha}: 0.4 \mu \mathrm{g} / \mathrm{kg} \\
\mathrm{CC}_{\beta}: 0.5 \mu \mathrm{g} / \mathrm{kg} \text { for } \\
\text { muscle }\end{array}$ & 60.0 for muscle & Dubois, Pierret, and Delahaut (2004) \\
\hline LC-MS & Muscle & 14 & LSE (acetonitrile) & LOQ: $0.1-0.2 \mu \mathrm{g} / \mathrm{kg}$ & 79.5-109.9 & Shao et al. (2009) \\
\hline LC-MS & Muscle & 41 & Different LSE; different SPE & $\begin{array}{l}\mathrm{CC}_{\alpha}: 2.29 \mu \mathrm{g} / \mathrm{kg} \\
\mathrm{CC}_{\beta}: 3.89 \mu \mathrm{g} / \mathrm{kg}\end{array}$ & $29.0-87.0$ & Stubbings and Bigwood (2009) \\
\hline LC-MS & $\begin{array}{l}\text { Eggs } \\
\text { Liver } \\
\text { Muscle }\end{array}$ & 2 & LSE (acetonitrile); SPE & $\begin{array}{l}\text { LOD: } 0.33-2.12 \mu \mathrm{g} / \mathrm{kg} \\
\text { LOQ: } 0.92-5.38 \mu \mathrm{g} / \mathrm{kg}\end{array}$ & $99.0-101.0$ & $\begin{array}{l}\text { Olejnik, Szprengier-Juszkiewicz, and } \\
\text { Jedziniak (2011) }\end{array}$ \\
\hline LC-MS & Eggs Muscle & 43 & $\begin{array}{l}\text { QuEChERS (acetonitrile; acetonitrile } \\
+ \text { formic acid) }\end{array}$ & LOQ: $1 \mu \mathrm{g} / \mathrm{kg}$ & $67.6-89.4$ & Nakajima et al. (2012) \\
\hline LC-MS & $\begin{array}{l}\text { Eggs } \\
\text { Kidney } \\
\text { Liver } \\
\text { Muscle } \\
\text { Skin/fat }\end{array}$ & 1 & LSE (acetonitrile); filtration (PTFE) & $\begin{array}{l}\text { LOD: }<3.0 \mu \mathrm{g} / \mathrm{kg} \\
\text { LOQ: } 20.0 \mu \mathrm{g} / \mathrm{kg}\end{array}$ & 89.0 & Coleman et al. (2014) \\
\hline LC-MS & Feed & 11 & LSE (acetonitrile) & $\begin{array}{l}\mathrm{CC}_{\alpha}: 532 \mu \mathrm{g} / \mathrm{kg} \\
\mathrm{CC}_{\beta}: 564 \mu \mathrm{g} / \mathrm{kg}\end{array}$ & 97.3 & Cronly et al. (2011) \\
\hline LC-MS & $\begin{array}{l}\text { Liver } \\
\text { Muscle }\end{array}$ & 18 & LSE (acetonitrile and propanol + salts) & $\begin{array}{l}\text { LOD: } 91 \mu \mathrm{g} / \mathrm{kg} \\
\text { LOQ: } 305 \mu \mathrm{g} / \mathrm{kg}\end{array}$ & $97-99$ & (Matus \& Boison, 2016) \\
\hline LC-MS & $\begin{array}{l}\text { Eggs } \\
\text { Feed }\end{array}$ & 5 & LSE (organic solvent) & $\begin{array}{l}\mathrm{CC}_{\alpha}: 1 \mu \mathrm{g} / \mathrm{kg} \\
\mathrm{CC}_{\beta}: 1.2 \mu \mathrm{g} / \mathrm{kg} \text { in eggs } \\
\mathrm{CC}_{\alpha}: 5.8 \mu \mathrm{g} / \mathrm{kg} \\
\mathrm{CC}_{\beta}: 8.6 \mu \mathrm{g} / \mathrm{kg} \text { in feed }\end{array}$ & $96.3-101.2$ & $\begin{array}{l}\text { Mortier, Daeseleire, and Van Peteghem } \\
\text { (2005) }\end{array}$ \\
\hline LC-MS & Muscle & 20 & $\begin{array}{l}n \text {-Hexane defatting; LSE (acetonitrile); } \\
\text { SPE (silica and C18) }\end{array}$ & LOQ: $5-50 \mu \mathrm{g} / \mathrm{kg}$ & $84.8-105.0$ & Yue et al. (2013) \\
\hline LC-MS & $\begin{array}{l}\text { Litter } \\
\text { Liver } \\
\text { Muscle }\end{array}$ & 1 & $\begin{array}{l}\text { LSE (ethyl acetate); liquid-liquid } \\
\text { partitioning with acetonitrile-hexane; } \\
\text { purification (alumina) }\end{array}$ & LOD: $20 \mu \mathrm{g} / \mathrm{kg}$ & - & Penz, Vieira, and Ludtke (1999) \\
\hline LC-MS & Litter & 6 & LSE (methanol) & - & $>70.0$ & $\begin{array}{l}\text { Furtula, Hannah, Wetzstein, and } \\
\text { Englar (2005) }\end{array}$ \\
\hline LC-MS & Litter & 5 & $\begin{array}{l}\text { LSE (methanol); filtration (glass } \\
\text { microfiber) }\end{array}$ & $\begin{array}{l}\text { LOD: } 0.5 \mu \mathrm{g} / \mathrm{kg} \\
\text { LOQ: } 2 \mu \mathrm{g} / \mathrm{kg}\end{array}$ & 64.0 & Furtula, Huang, and Chambers (2009) \\
\hline LC-MS & $\begin{array}{l}\text { Eggs } \\
\text { Muscle }\end{array}$ & 20 & LSE (acetonitrile) & $\begin{array}{l}\mathrm{CC}_{\alpha}: 4579 \mu \mathrm{g} / \mathrm{kg} \\
\mathrm{CC}_{\beta}: 6060 \mu \mathrm{g} / \mathrm{kg} \text { in } \\
\text { muscle } \\
\mathrm{CC}_{\alpha}: 106 \mu \mathrm{g} / \mathrm{kg} \\
\mathrm{CC}_{\beta}: 117 \mu \mathrm{g} / \mathrm{kg} \text { in eggs } \\
\text { LOQ: } 10 \mu \mathrm{g} / \mathrm{kg} \text { for } \\
\text { both }\end{array}$ & $76.0-77.0$ & Moloney et al. (2012) \\
\hline LC-MS & $\begin{array}{l}\text { Eggs } \\
\text { Honey } \\
\text { Milk } \\
\text { Muscle }\end{array}$ & $>160$ & $\begin{array}{l}\text { LSE (acetonitrile); no additional } \\
\text { purification step }\end{array}$ & - & - & Robert et al. (2013) \\
\hline LC-MS & $\begin{array}{l}\text { Eggs } \\
\text { Muscle }\end{array}$ & 20 & LSE (acetonitrile) & $\begin{array}{l}\mathrm{CC}_{\alpha}: 4579 \mu \mathrm{g} / \mathrm{kg} \\
\mathrm{CC}_{\beta}: 6060 \mu \mathrm{g} / \mathrm{kg} \text { in } \\
\text { muscle } \\
\mathrm{CC}_{\alpha}: 106 \mu \mathrm{g} / \mathrm{kg} \\
\mathrm{CC}_{\beta}: 117 \mu \mathrm{g} / \mathrm{kg} \text { in eggs } \\
\mathrm{LOQ}: 10 \mu \mathrm{g} / \mathrm{kg} \text { for } \\
\text { both }\end{array}$ & $76.0-77.0$ & Moloney et al. (2012) \\
\hline SPR Biosensor & Eggs & 1 & LSE (acetonitrile) & LOD: $5 \mu \mathrm{g} / \mathrm{kg}$ & - & $\begin{array}{l}\text { McCarney, Traynor, Fodey, Crooks, } \\
\text { (continued on next page }\end{array}$ \\
\hline
\end{tabular}


Table 4 (continued)

\begin{tabular}{|c|c|c|c|c|c|c|}
\hline $\begin{array}{l}\text { Analytical } \\
\text { techniques }\end{array}$ & Matrices & $\begin{array}{l}\text { Number of } \\
\text { analytes }\end{array}$ & Sample preparation & Sensitivity & $\begin{array}{l}\text { Recovery rates } \\
(\%)\end{array}$ & Reference \\
\hline & $\begin{array}{l}\text { Breast } \\
\text { Liver } \\
\text { Muscle }\end{array}$ & & & & & and Elliott (2003) \\
\hline
\end{tabular}

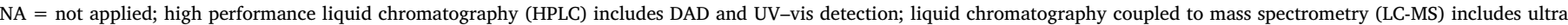
high performance liquid chromatography (UHPLC); tandem mass spectrometry (MS/MS); qToF (quadrupole time-of-flight).

possibly due to the difficulty of the derivatization process (Clarke et al., 2014).

Currently, mass spectrometry (MS) has been widely used because of its high selectivity and specificity. Coupled to liquid chromatography (LC-MS), it has allowed the determination of several classes of veterinary drugs in very low concentrations, joining a robust and efficient separation with high sensitivity detection. Thus, the unequivocal identification of the analytes in the samples is achieved by their retention times and mass spectra. The majority of LC-MS has been carried out with tandem-mass spectrometric detection, often abbreviated as LC-MS/MS (Kruve et al., 2015). Chemical coccidiostats typically produce $[\mathrm{M}+\mathrm{H}]^{+}$or $[\mathrm{M}-\mathrm{H}]^{-}$precursor ions in electrospray ionization (ESI) mode. Most early, LC-MS applications were tested for the most widely used coccidiostats, mainly comprising ionophores and nicarbazin in eggs and poultry tissues (Clarke et al., 2014). A method capable to simultaneously analyze four ionophores and DNC in eggs and liver was developed (Matabudul, Lumley, \& Points, 2002). Dubois, Pierret, and Delahaut (2004) developed an early LC-MS/MS method for nine coccidiostats in egg and muscle, capable of measuring residues under $0.6 \mu \mathrm{g} / \mathrm{kg}$. Many researchers followed this trend by developing methods for some or all of the 11 coccidiostats with non-target EU MRLs (Cronly et al., 2011; Shao et al., 2009). Extensive methods have been developed that comprise as many as 20 coccidiostats in poultry products. Moloney et al. (2012) reported the development of a LC-MS/MS method for the determination of 20 coccidiostat residues to $1 \mu \mathrm{g} / \mathrm{kg}$ in egg and muscle. Yue et al. (2013) similarly developed a method for 20 coccidiostats in meat. LOQs ranged from 5 to $50 \mu \mathrm{g} / \mathrm{kg}$. Multiclass methods for the determination of a wide range of feed additive residues in food and feed samples (Protasiuk, Olejnik, SzprengierJuszkiewicz, Jedziniak, and Zmudzki (2015) have been developed. Surprisingly, few coccidiostats are included in many of these methods. This may be because coccidiostats are regarded as feed additives rather than veterinary drugs or that they cannot be easily accommodated in sample preparation steps used in these methods. Stubbings and Bigwood (2009) reported a multiclass LC-MS/MS method for the determination of veterinary drug residues (including ionophores, DNC and nitroimidazoles) in chicken muscle following QuEChERS sample preparation. Coleman et al. (2014) validated a LC-MS/MS method applicable for the determination and confirmation of DNC in chicken liver, kidney, muscle, skin with adhering fat tissues, and in eggs.

Nakajima et al. (2012) simultaneously quantified 39 feed additives in chicken muscle by LC-MS/MS, including nicarbazin (DNC). Robert et al. (2013) suggested the same technique to identify 160 feed additives including nicarbazin in products of animal origin. The target value for the compounds has been defined as half of the maximum allowed value, according to the current regulatory limits, being adopted for most of the substances of interest. The control of these additives through multiresidue methods conducted accordingly can assure food security in a less costly and more effective way. Thus, an effective preparation and extraction procedure associated to LC-MS can be used as a powerful technique for monitoring feed additives in products of animal origin.

\subsection{Analytical performance and decision-making}

Regardless of the adopted analytical technique, the reliability of the results shall be checked through validation procedures (ISO, 2010). Among the most commonly used validation guides are those proposed by IUPAC, EURACHEM, ISO, SANCO, AOAC, FAO, among others. In the meantime, the Commission Decision 657/2002/EC is considered an appropriate guide for the validation of analytical methods for residues of veterinary drugs by LC-MS (EC, 2002). It is currently the validation guide with the largest number of publications involving its use, showing great international acceptance (Matus \& Boison, 2016; Wang et al., 2014).

On the other hand, the correct interpretation of the analytical results is fundamental because it will support important decision making, either by quality control and government agencies. Impacting consequences, such as the recall of products, destruction of large batches, application of fines, administrative and judicial proceedings, and damages to both human and animal health are some of the examples (Molognoni, Ploêncio, Machado, \& Daguer, 2017). In addition, economic sanctions and barriers to international food trade have been based on the often-poor chemical metrology of some producing countries. In this sense, analytical capacity goes beyond modern analytical tools, since the correct treatment of analytical data turns into an important and crucial technical task.

The result of a measurement is only an approximation of a specific quantity of a measure. Decisions can only be clearly taken when the measure is accompanied by a quantitative statement of its measurement uncertainty (MU) (Taylor, 2009). Top-down approaches to estimate MU are likely most appropriate when analytical procedures are routinely applied to a large number of analytes. Nicarbazin is usually assessed with several other coccidiostats in multi-residue simultaneous methods (Cronly et al., 2011; Valese et al., 2017). The use of intra-laboratory reproducibility is a good MU estimator, as recommended by SANCO/ 2004/2726 (SANCO, 2008) and ISO/TS 21748:2004 (ISO, 2010). Several studies have been demonstrated the use of top-down approaches to estimate MU due to the analysis of nicarbazin and other compounds (Cronly et al., 2011; Dabalus Islam, Schweikert Turcu, \& Cannavan, 2008; Valese et al., 2017). Type A uncertainty sources experimentally obtained during validation approaches, such as precision, bias, and residues from analytical curves, among others, may be initially overestimated. On the other hand, these values serve as a basis for the improvement of measuring quality, because they tend to decrease, while the number of measurements increases due to routine analysis (Molognoni et al., 2017). Furthermore, the use of internal standardization can decrease the biggest sources of uncertainty, such as random effects due to analysts and equipment which can take place in long analytical processes with (Molognoni, Valese, Lorenzetti, Daguer, \& Lindner, 2016). In this context, the use of deuterated nicarbazin (DNC-D8) as an internal standard is highly recommended in order to decrease type A uncertainty sources (Valese et al., 2017).

The limit of decision $\left(\mathrm{CC}_{\alpha}\right)$ and the detection capability $\left(\mathrm{CC}_{\beta}\right)$ are parameters defined by Commission Decision 657/2002/EC which measure the performance of the analytical procedure and help the interpretation of results. Those limits take in account the measuring error in the concentration level which can request some decision making 
("interest level"). Despite being an alternative to the MU, they shall only be used when regulatory limits are clearly set, or when banned substances are being dealt with (Molognoni et al., 2016). The $\mathrm{CC}_{\alpha}$ is the limit from which one can conclude that a sample is non-compliant with a probability of a $\alpha$ error (EC, 2002). For instance, the regulatory limit for nicarbazin in tissue is $200 \mu \mathrm{g} / \mathrm{kg}$. By taking into account the respective experimental $\alpha$ error, such as $28 \mu \mathrm{g} / \mathrm{kg}$, achieved by Capurro, Danaher, Anastasio, Cortesi, and O'Keeffe (2005) (Table 4), only samples with concentrations above $228 \mu \mathrm{g} / \mathrm{kg}$ could be considered noncompliant. On the other hand, $\mathrm{CC}_{\beta}$ is the lowest content of the analyte that can be quantified in a sample with a probability of $\beta$ error (EC, 2002). Considering the $\mathrm{CC}_{\beta}$ in decision-making implies that laboratories are able to present their minimum required performance level (MRPL). MRPL can be defined as the minimum nicarbazin concentration that can be detected or quantitated by the analytical method, considering that it is a banned analyte. As it can be observed in Table 4, there is a wide range among $\mathrm{CC}_{\alpha}$ and $\mathrm{CC}_{\beta}$ values for nicarbazin analytical methods, since those parameters are experimentally obtained from error sources and deviations. Thus, different error profiles are expected, depending on the analytical technique, laboratory personnel (analysts), and validation levels.

Anyway, the scope of a measurement result must always be estimated, regardless of the approach used, since the measure becomes critical when compliance with regulatory limits should be evaluated or compared (Zamengo, Frison, Gregio, Orrù, \& Sciarrone, 2011).

\section{Occurrence of DNC residues}

The main concern about nicarbazin use in broiler production is the possibility of residue in meat exceeding regulatory limits. Otherwise, it is considered safe for consumption. Though many authorities consider the withdrawal period of feed additives enough to avoid residues in edible tissue, contaminations still occur (Clarke et al., 2014; Kantiani, Llorca, Sanchís, Farré, \& Barceló, 2010; MAPA, 2015a; Danaher et al., 2008). In this section, details about nicarbazin active substance (DNC) residue in chicken tissues and litter, besides the possible reasons for tissue contamination are discussed. Results of monitoring programs from Brazilian, European and American official reports are presented.

\subsection{Edible chicken tissues}

The pharmacokinetic data of nicarbazin shows HDP is eliminated mainly in urine (90\%) with higher excretion than DNC, which is excreted primarily in feces (46\%) together with its metabolites (EFSA, 2010a; JECFA, 1999). Therefore, both HDP and DNC are absorbed separately, being DNC the main concern in meat contamination, because probably $54 \%$ remains in the broiler organism.

DNC is recognized as the marker residue in broiler tissues, based on in vivo trial with broilers fed $125 \mathrm{mg} / \mathrm{kg}$ nicarbazin. After 5-day withdrawal, a continuous decrease to nearly zero (negligible level) was observed for muscle, skin/fat and kidney. Meanwhile, liver residue showed only slightly decrease, still presenting $23-48 \%$ of the initial DNC level. From there on, liver has been considered the target tissue for DNC residues (EFSA, 2010a; JECFA, 1999).

Few studies evaluated DNC in tissues (Cannavan \& Kennedy, 2000; EFSA, 2010b; O'Keeffe, Capurro, Danaher, Campbell, \& Elliott, 2007; Penz, Vieira, \& Ludtke, 1999). In Brazil, the effect of poultry litter reuse was evaluated up to three flocks considering a 7-day withdrawal period. Nicarbazin was added to feed (at 100 or $125 \mathrm{mg} / \mathrm{kg}$ ) as the only anticoccidial or in association with maduramicin (40:5 nicarbazin: maduramicin). Liver presented the highest DNC concentration for all growouts, while in breast $13 \mu \mathrm{g} / \mathrm{kg}$ of DNC residues were detected in the second grow-out, but no detection in the third cycle. In litter, DNC residues persisted up to three grow-outs, even removing nicarbazin from feed after the first trial (Penz, Vieira, \& Ludtke, 1999). Cannavan and Kennedy (2000) studied increased doses of nicarbazin $(0.2,0.4$,
1.6, 4.2 and $13.5 \mathrm{mg} / \mathrm{kg}$ ) in feed, with liver showing the highest nicarbazin concentration $(200 \mu \mathrm{g} / \mathrm{kg})$. Otherwise, in muscle, residues were in acceptable limits. The authors concluded that to prevent DNC residue occurrence in chicken liver, a maximum of $2.4 \mathrm{mg} / \mathrm{kg}$ nicarbazin in feed should be used. O'Keeffe et al. (2007) evaluated the effect of the withdrawal in broilers, observing that up to $1.6 \mathrm{mg} / \mathrm{kg}$ of nicarbazin (as DNC) may still be present in liver after a six day withdrawal. The EFSA (2010a) reported that broilers fed $125 \mathrm{mg} / \mathrm{kg}$ nicarbazin for 28 days had their tissues evaluated during 14 days after withdrawal. DNC decreased in all tissues, especially in liver, which presented $9.25,0.45$ and $<0.05 \mathrm{mg} / \mathrm{kg}$ in the first, fifth and seventh days, respectively.

There is a huge variability in the results from these mentioned studies which may be due to the different nicarbazin concentrations in feed (from 0.2 to $125 \mathrm{mg} / \mathrm{kg}$ ), different withdrawal periods (from 1 to 9 days), analytical methodologies, and the poultry litter reuse that varied from no litter reuse until three flocks. All these factors may have influenced this huge variability.

\subsection{Monitoring results in Brazil, United States and European Union}

The National Plan of Residues and Contaminants Control (PNCRC) is a Brazilian official program for inspection and surveillance of food derived from plant and animal origin. PNCRC for animal products covers meat, milk, honey, eggs and fish. Samples are collected in several slaughterhouses (Mauricio, Lins, \& Alvarenga, 2009). Regarding the anticoccidial in broilers, results of the last 5-year (2011-2015) monitoring detected 12 noncompliances, all related to nicarbazin active compound (MAPA, 2011, 2012, 2013, 2014, 2015a). Currently, it is evaluated only in broiler muscle. Especially in 2015, seven noncompliances out of 457 samples were observed (MAPA, 2015a), representing a rate of $1.53 \%$. These deviations were corroborated by Japanese authorities in the past, when DNC residues in imported broiler meat were detected (Spínosa et al., 2014), while recently no violations occur.

The European Union residue monitoring program recorded noncompliances. Both liver and muscle from broilers are evaluated. Up to 2010 , when DNC limit was $200 \mu \mathrm{g} / \mathrm{kg}, 46$ violations in poultry were reported. From 2011 on, after increasing the MRLs, only two noncompliances were reported for liver (EC, 2010c, 2011, 2012, 2013, 2014).

In the USA, the National Residue Program (NRP) monitors meat, poultry and egg products. This agency considers a priority list of feed additives, which receive a score each year. Based on this score, the additive may be monitored or not in the current year. Comparing to other feed additives, nicarbazin has been considered of low priority (low score) since 1994 and there on has not being monitored (USDAFSIS, 2005, 2013, 2014).

\subsection{Possible causes of contamination in broiler tissues}

The cause of DNC residues in poultry is hard to be attributed to only one specific factor; however, it may be linked to noncompliance in the feed mill or at the farm (Campbell et al., 2007; O'Keeffe et al., 2007). Nicarbazin crystals are highly electrostatic and present some problems during dry blending. Improper cleaning of silos, hoppers and feeding lines between feed batches, as well as feed unloading to the wrong silo, contamination during preparation or transport have been reported (Riviere \& Papich, 2009; Verstraete, 2013). Besides cross contamination among feed batches, noncompliance may also be related to overdosage or improper withdrawal (Dorne et al., 2013; O'Keeffe et al., 2007). Coprophagy (feces ingestion) is usual in avian species and should also be considered as a contamination route, especially for broilers housed on deep litter. This continued exposure to nicarbazin (DNC) may lead to tissue contamination after feed withdrawal due to DNC in the litter or in the feces (O'Keeffe et al., 2007; Olejnik et al., 2011). As observed by 
Cannavan and Kennedy (2000), chickens reared on litter showed DNC content in muscle about six fold higher $(14 \mathrm{mg} / \mathrm{kg})$ than those reared in cages $(2.4 \mathrm{mg} / \mathrm{kg})$. Because poultry litter reuse is not usual in Europe, no information regarding food safety in poultry tissues due to prolonged broiler litter use were reported by EFSA. However, either in Brazil (Roll, Dai Pra, \& Roll, 2011) or in the USA, litter reuse is a common practice, lowering costs and reducing environmental impacts.

Literature is scarce regarding nicarbazin active substance degradation in broiler litter. Only one research from Penz, Vieira, and Ludtke (1999) evaluated the cumulative effect of litter reuse during three grow-outs and found high amounts of DNC residue, using colorimetry. With a new analytical approach, using liquid chromatography coupled to mass spectrometry (Table 4), Furtula, Hannah, Wetzstein, and Englar (2005) evaluated commercial farms and reported DNC residues in poultry litter (without reuse), ranging from 14 to $23 \mathrm{mg} / \mathrm{kg}$. In another survey conducted by the same group, DNC values in broiler litter ranged from 1.28 to $10.95 \mathrm{mg} / \mathrm{kg}$ (Furtula et al., 2009). The persistence of DNC residues in broiler litter was confirmed further in controlled conditions (Furtula et al., 2010).

Summarizing, if broiler litter contains high amounts of DNC, it may be one of the chicken meat contamination causes. However, much has to be investigated for broilers housed on reused litter, once the only published report was based on colorimetry, which has been replaced by more sensitive and accurate analytical methods.

\section{Prospects}

Nicarbazin is used in intensive chicken farming since the 1950s, with strategic importance in prophylactic programs to avoid the undesirable effects of coccidiosis. More recently, a special concern on food safety has turned the attention to this synthetic substance, considering the possibility of residues in poultry products. Based on animal toxicological studies, high doses of nicarbazin would cause negative effects in humans such as weight loss, liver abnormalities and kidney problems. However, genotoxic risks have not been reported. It is worth mentioning that MRL has been determined considering the ADI of the residue marker (DNC) and consumer daily exposition to this residue. Therefore, the harmful effects can be avoided if the DNC residue in food is kept below the recommended MRL and if $p$-nitroaniline in nicarbazin does not exceed $0.1 \%$.

It seems unlikely that consumption of usual daily quantities of poultry products, considering the ADIs, would pose any risk to human health regarding DNC residues. In order to improve food safety, it is important to follow safety measures such as the recommended dosages and withdrawal periods, caution in feed production to avoid cross contamination and consequently tissue contamination. Also, monitoring programs are essential to check if recommended MRLs are within the regulated ranges and more accurate analytical methods should be developed. Researches considering litter reuse, especially where this procedure is common are needed. It is expected that such studies will help to redefine strategies in utilizing nicarbazin as a feed additive and therefore, contribute to reduce even more the occurrence of noncompliances in monitoring programs.

A comprehensive review has been carried out in this paper on the analysis of DNC residues. LC-MS/MS is the technique of choice to analyze a broad range of coccidiostat residues at extremely low levels in food. Alternatively, immunochemical methods can be applied but are more suitable for single residue analysis. Non-compliant DNC levels continue to be detected in chicken meat. In the future, it is expected that more reliable and sensitive methods will be able to detect coccidiostat residues in food in order to assure both, the MRL and food safety.

Future research should concentrate on the development of multiresidue methods. Sample preparation procedures need to reduce ion suppression or enhancement effects caused by sample matrix in order to improve accuracy. Alternatively, additional stable isotopically labelled standards should be synthesized to compensate for ionization effects.
In order to improve the specificity of immunoassay techniques, high quality antibodies still need to be produced. Furthermore, the uniform response of broad-specificity antibodies, as well as assay automation and application to real samples, need to be improved in order to quick respond the needs of the productive chain.

\section{Financial support}

The authors thank the following National Agencies: CAPES (1533827) (Coordenação de Aperfeiçoamento de Pessoal de Nível Superior - Coordination for the Improvement of Higher Education Personnel); CNPq (421626/2016-0) (Conselho Nacional de Desenvolvimento Científico e Tecnológico - National Council for Scientific and Technological Development).

\section{References}

ABPA (2016). Annual report. (Retrieved from http://abpa-br.com.br/storage/files/versao_final_para_envio_digital_1925a_final_abpa_relatorio anual_2016_portugues_web1.pdf).

Barker, S. A. (2007). Matrix solid phase dispersion (MSPD). Journal of Biochemical and Biophysical Methods, 70(2), 151-162. http://dx.doi.org/10.1016/j.jbbm.2006.06. 005.

Beier, R. C., Ripley, L. H., Young, C. R., \& Kaiser, C. M. (2001). Production, characterization, and cross-reactivity studies of monoclonal antibodies against the coccidiostat nicarbazin. Journal of Agricultural and Food Chemistry, 49, 4542-4552.

Berchieri Júnior, A., Silva, E. N., Fábio, J. D., Sesti, L., \& Zuanaze, M. A. F. (2009), Doenças nas aves (2nd ed.). Campinas: FACTA - Fundação APINCO de Ciência e Tecnologia Avícolas.

Biofarma (2016). Biofarma. (Retrieved from http://en.biofarmaweb.com.ar/drugs/mngrow).

Blake, D. P., \& Tomley, F. M. (2014). Securing poultry production from the ever-present Eimeria challenge. Trends in Parasitology, 30(1), 12-19. http://dx.doi.org/10.1016/j. pt.2013.10.003.

Boscher, A., Guignard, C., Pellet, T., Hoffmann, L., \& Bohn, T. (2010). Development of a multi-class method for the quantification of veterinary drug residues in feedingstuffs by liquid chromatography-tandem mass spectrometry. Journal of Chromatography A, 1217(41), 6394-6404. http://dx.doi.org/10.1016/j.chroma.2010.08.024.

Campbell, K., Fodey, T., Flint, J., Danks, C., Danaher, M., O'Keeffe, M., ... Elliott, C. (2007). Development and validation of a lateral flow device for the detection of nicarbazin contamination in poultry feeds. Journal of Agricultural and Food Chemistry, 55(6), 2497-2503. http://dx.doi.org/10.1021/jf062811d.

Cannavan, A., \& Kennedy, D. G. (2000). Possible causes of nicarbazin residues in chicken tissues. Food Additives and Contaminants, 17(12), 1001-1006. http://dx.doi.org/10. 1080/0265203001001325.

Capurro, E., Danaher, M., Anastasio, A., Cortesi, M. L., \& O'Keeffe, M. (2005). Efficient HPLC method for the determination of nicarbazin, as dinitrocarbanilide in broiler liver. Journal of Chromatography B, 822, 154-159. http://dx.doi.org/10.1016/j. jchromb.2005.05.033.

Casado, N., Morante-Zarcero, S., Pérez-Quintanilla, D., \& Sierra, I. (2016). Application of a hybrid ordered mesoporous silica as sorbent for solid-phase multi-residue extraction of veterinary drugs in meat by ultra-high-performance liquid chromatography coupled to ion-trap tandem mass spectrometry. Journal of Chromatography A, 1459, 24-37. http://dx.doi.org/10.1016/j.chroma.2016.06.077.

Chapman, H. D. (2014). Milestones in avian coccidiosis research: A review. Poultry Science, 93(3), 501-511. http://dx.doi.org/10.3382/ps.2013-03634.

Clarke, L., Fodey, T. L., Crooks, S. R. H., Moloney, M., O'Mahony, J., Delahaut, P., ... Danaher, M. (2014). A review of coccidiostats and the analysis of their residues in meat and other food. Meat Science, 97(3), 358-374. http://dx.doi.org/10.1016/j. meatsci.2014.01.004.

Coleman, M. R., Rodewald, J. M., Brunelle, S. L., Nelson, M., Bailey, L., \& Burnett, T. J. (2014). Determination and confirmation of nicarbazin, measured as 4,4-dinitrocarbanilide (DNC), in chicken tissues by liquid chromatography with tandem mass spectrometry: First action 2013.07. Journal of AOAC International, 97(2), 630-640. http://dx.doi.org/10.5740/jaoacint.13-197.

Connolly, L., Fodey, T. L., Crooks, S. R. H., Delahaut, P., \& Elliott, C. T. (2002). The production and characterisation of dinitrocarbanilide antibodies raised using antigen mimics. Journal of Immunological Methods, 264, 45-51.

Cronly, M., Behan, P., Foley, B., Malone, E., Shearan, P., \& Regan, L. (2011). Determination of eleven coccidiostats in animal feed by liquid chromatography-tandem mass spectrometry at cross contamination levels. Analytica Chimica Acta, 700(1-2), 26-33. http://dx.doi.org/10.1016/j.aca.2010.11.001.

Dabalus Islam, M., Schweikert Turcu, M., \& Cannavan, A. (2008). Comparison of methods for the estimation of measurement uncertainty for an analytical method for sulphonamides. Food Additives \& Contaminants. Part A, Chemistry, Analysis, Control, Exposure \& Risk Assessment, 25(12), 1439-1450. http://dx.doi.org/10.1080/02652030802189765.

Danaher, M., Campbell, K., O'Keeffe, M., Capurro, E., Kennedy, G., \& Elliott, C. (2008). Survey of the anticoccidial feed additive nicarbazin (as dinitrocarbanilide residues) in poultry and eggs. Food Additives \& Contaminants, 25(1), 32-40. http://dx.doi.org/10.1080/ 02652030701552956. 
Dorne, J. L. C. M., Fernández-Cruz, M. L., Bertelsen, U., Renshaw, D. W., Peltonen, K., Anadon, A., ... Fink-Gremmels, J. (2013). Risk assessment of coccidostatics during feed cross-contamination: Animal and human health aspects. Toxicology and Applied Pharmacology, 270(3), 196-208. http://dx.doi.org/10.1016/j.taap.2010.12.014.

Dubois, M., Pierret, G., \& Delahaut, P. (2004). Efficient and sensitive detection of residues of nine coccidiostats in egg and muscle by liquid chromatography-electrospray tandem mass spectrometry. Journal of Chromatography B, 813, 181-189. http://dx. doi.org/10.1016/j.jchromb.2004.09.039.

EC (2002). European Commission Decision 2002/657/EC implementing Council Directive 92/23/EC concerning the performance of analytical methods and the in terpretation of results. Official Journal of the European Communities, L221, 8-36.

EC (2010a). Commission Regulation (EU) no. 875/2010 of 5 October 2010 concerning the authorisation for 10 years of an additive in feedingstuffs. Official Journal of the European Union, 263, 4-6 (Retrieved from https://www.vmd.defra.gov.uk/ ProductInformationDatabase/SFA_Documents/SFA_315211.PDF).

EC (2010b). Commission Regulation (EU) no. 885/2010 of 8 October 2010 concerning the authorisation of the preparation of narasin and nicarbazin as a feed additive for chickens for fattening. Official Journal of the European Union, 265, 5-8 (Retrieved from http://eur-lex.europa.eu/legal-content/EN/TXT/?uri = CELEX:32010R0885).

EC (2010c). Commission staff working document on the implementation of national residue monitoring plans in the Member States in 2010 (Council Directive 96/23/EC). (Retrieved from https://ec.europa.eu/food/sites/food/files/safety/docs/cs_vet-med-residues_workdoc_2010_en.pdf).

EC (2011). Commission staff working document on the implementation of national residue monitoring plans in the Member States in 2011 (Council Directive 96/23/EC). (Retrieved from https://ec.europa.eu/food/sites/food/files/safety/docs/cs_vet-med-residues_workdoc_2011_en.pdf).

EC (2012). Commission staff working document on the implementation of national residue monitoring plans in the Member States in 2012 (Council Directive 96/23/EC). (Retrieved from http://ec.europa.eu/food/safety/docs/cs_vet-med-residues_workdoc_2012_en.pdf).

EC (2013). Report on the implementation of national residue monitoring plans in the Member States in 2013 (Council Directive 96/23/EC). (Retrieved from http://ec.europa.eu/ food/safety/docs/cs_vet-med-residues_workdoc_2013_en.pdf).

EC (2014). Report on the implementation of national residue monitoring plans in the Member States in 2014 (Council Directive 96/23/EC). (Retrieved from http://ec.europa.eu/ food/safety/docs/cs_vet-med-residues_workdoc_2014_en.pdf).

EFSA (2003). Opinion of the scientific panel on additives and products or substances used in animal feed on a request from the Commission on the efficacy and safety of the coccidiostat Koffogran. EFSA Journal, 16, 1-40.

EFSA (2010a). Scientific Opinion on the safety and efficacy of Koffogran (nicarbazin) as a feed additive for chickens for fattening. EFSA Journal, 8(3), 1551 1-40. (10.2903/ j.efsa.2010.1551)

EFSA (2010b). Scientific Opinion on the safety and efficacy of Maxiban ${ }^{\circledast}$ G160 (narasin and nicarbazin) for chickens for fattening. EFSA Journal, 8(4), 1574 1-45. (10.2903/ j.efsa.2010.1574).

Elanco (2016). Maxiban ${ }^{\circledast}$ 80/80 Premix. Retrieved from http://www.elanco.com.br/ products-services/poultry/maxiban.aspx).

FAO/WHO (2015). Maximum Residue Limits (MRLs) and Risk Management Recommendations (RMRs) for residues of veterinary drugs in foods CAC/MRL 2-2015. (Retrieved from http://www.fao.org/fao-who-codexalimentarius/standards/veterinary-drugs-mrls/pt/).

Furtula, V., Farrell, E. G., Diarrassouba, F., Rempel, H., Pritchard, J., \& Diarra, M. S. (2010). Veterinary pharmaceuticals and antibiotic resistance of Escherichia coli isolates in poultry litter from commercial farms and controlled feeding trials. Poultry Science, 89(1), 180-188. http://dx.doi.org/10.3382/ps.2009-00198.

Furtula, V., Hannah, H., Wetzstein, M., \& Englar, R. (2005). Veterinary pollutants in poultry waste. Proceeding of the 9th International Conference on Environmental Science and Technology Vol B - Poster Presentations, (September) (pp. B225-B230).

Furtula, V., Huang, L., \& Chambers, P. A. (2009). Determination of veterinary pharmaceuticals in poultry litter and soil by methanol extraction and liquid chromatographytandem mass spectrometry. Journal of Environmental Science and Health. Part. B, 44, 717-723. http://dx.doi.org/10.1080/03601230903163863.

GPO (2012). Title 21 - Food and drugs. Chapter I - Food and drug administration, department of health and human services. Subchapter e-animal drugs, feeds, and related products part 556 - tolerances for residues of new animal drugs in food. Subpart B - Specific Tol. (Retrieved from https://www.gpo.gov/fdsys/pkg/CFR-2012-title21-vol6/pdf/CFR2012-title21-vol6-sec556-445.pdf).

Gressler, V., Franzen, A. R. L., Lima, G. J. M. M., Tavernari, F. C., Dalla Costa, O. A., \& Feddern, V. (2016). Development of a readily applied method to quantify ractopamine residue in meat and bone meal by QuEChERS-LC-MS/MS. Journal of Chromatography B, 1015-1016, 192-200. http://dx.doi.org/10.1016/j.jchromb.2016. 01.063.

Guo, C., Wang, M., Xiao, H., Huai, B., Wang, F., Pan, G., ... Liu, Y. (2016). Development of a modified QuEChERS method for the determination of veterinary antibiotics in swine manure by liquid chromatography tandem mass spectrometry. Journal of Chromatography B, 1027, 110-118. http://dx.doi.org/10.1016/j.jchromb.2016.05. 034.

Huertas-Pérez, J. F., Arroyo-Manzanares, N., Havlíková, L., Gámiz-Gracia, L., Solich, P., \& García-Campaña, A. M. (2016). Method optimization and validation for the determination of eight sulfonamides in chicken muscle and eggs by modified QuEChERS and liquid chromatography with fluorescence detection. Journal of Pharmaceutical and Biomedical Analysis, 124, 261-266. http://dx.doi.org/10.1016/j.jpba.2016.02. 040.

Huet, A.-C., Bienenmann-Ploum, M., Vincent, U., \& Delahaut, P. (2013). Screening methods and recent developments in the detection of anticoccidials. Analytical and
Bioanalytical Chemistry, 405(24), 7733-7751. http://dx.doi.org/10.1007/s00216013-7035-6.

Huet, A.-C., Mortier, L., Daeseleire, E., Fodey, T., Elliott, C., \& Delahaut, P. (2005). Development of an ELISA screening test for nitroimidazoles in egg and chicken muscle. Analytica Chimica Acta, 534(1), 157-162. http://dx.doi.org/10.1016/j.aca. 2004.06.037.

Huvepharma (2016). Monimax ${ }^{\circledast}$ (monensin/nicarbazin). (Retrieved from http:// www.huvepharma.com/products/monimaxr).

ISO (2010). International Organization for Standardization. ISO/TS 21748:2010. Guidance for the use of repeatability, reproducibility and trueness in measurement uncertainties estimation (1st ed.). Geneva, Switzerland: ISO.

JECFA (1999). Evaluation of certain veterinary drug residues in food. Rome. (Retrieved from http://apps.who.int/iris/bitstream/10665/42182/1/WHO_TRS_888.pdf).

Kanda, M., Ushiyama, K., Igusa, K., Murayama, M., Horie, M., Hirokado, M., \& Miyazaki, T. (2003). Simple determination of residual anticoccidial drugs (diclazuril and nicarbazin) in chicken tissues by HPLC. Journal of the Food Hygienic Society of Japan, 44(2), 110-113.

Kantiani, L., Llorca, M., Sanchís, J., Farré, M., \& Barceló, D. (2010). Emerging food contaminants: A review. Analytical and Bioanalytical Chemistry, 398(6), 2413-2427. http://dx.doi.org/10.1007/s00216-010-3944-9.

Kruve, A., Rebane, R., Kipper, K., Oldekop, M.-L., Evard, H., Herodes, K., ... Leito, I. (2015). Tutorial review on validation of liquid chromatography-mass spectrometry methods: Part I. Analytica Chimica Acta, 870, 29-44. http://dx.doi.org/10.1016/j.aca. 2015.02.017.

Li, Y.-F., Sun, Y.-M., Beier, R. C., Lei, H.-T., Gee, S., Hammock, B. D., ... Xu, Z.-L. (2017) Immunochemical techniques for multianalyte analysis of chemical residues in food and the environment: A review. TrAC Trends in Analytical Chemistry, 88, 25-40. http://dx.doi.org/10.1016/j.trac.2016.12.010.

MAPA (2011). SDA normative instruction no. 6, from February 25th, 2011.

MAPA (2012). SDA normative instruction no. 7, from April 4th, 2012.

MAPA (2013). SDA normative instruction no. 7, from March 27th, 2013.

MAPA (2014). Administrative ruling SDA \#60, from May 7th, 2014.

MAPA (2015a). Ordinance SDA no. 22, from April 7th, 2015.

MAPA (2015b). SDA normative instruction no. 13, from July 15th, 2015. National plan for control of residues and contaminants - PNCRC/2015.

MAPA (2015c). Tabela de aditivos antimicrobianos, anticoccidianos e agonistas com uso autorizado na alimentação animal. Table of antimicrobial additives, anticoccidials and agonists with authorized use in animal feedBrazil: Ministry of Agriculture, Livestock and Food Supply.

Matabudul, D. K., Crosby, N. T., \& Sumar, S. (1999). A new and rapid method for the determination of nicarbazin residues in poultry feed, eggs and muscle tissue using supercritical fluid extraction and high performance liquid chromatography. The Analyst, 124(4), 499-502.

Matabudul, D. K., Lumley, I. D., \& Points, J. S. (2002). The determination of 5 anticoccidial drugs (nicarbazin, lasalocid, monensin, salinomycin and narasin) in animal livers and eggs by liquid chromatography linked with tandem mass spectrometry (LCMS-MS). The Analyst, 127, 760-768 http://dx.doi.org/10.1039/b200872f.

Matus, J. L., \& Boison, J. O. (2016). A multi-residue method for 17 anticoccidial drugs and ractopamine in animal tissues by liquid chromatography-tandem mass spectrometry and time-of-flight mass spectrometry. Drug Testing and Analysis, 8, 465-476. http:// dx.doi.org/10.1002/dta.2019.

Mauricio, A. Q., Lins, E. S., \& Alvarenga, M. B. (2009). A National Residue Control Plan from the analytical perspective-The Brazilian case. Analytica Chimica Acta, 637(1-2), 333-336. http://dx.doi.org/10.1016/j.aca.2008.09.061.

McCarney, B., Traynor, I. M., Fodey, T. L., Crooks, S. R. H., \& Elliott, C. T. (2003). Surface plasmon resonance biosensor screening of poultry liver and eggs for nicarbazin residues. Analytica Chimica Acta, 483(1-2), 165-169. http://dx.doi.org/10.1016/ S0003-2670(02)01470-8.

Molognoni, L., Ploêncio, L. A. S., Machado, A. M. L., \& Daguer, H. (2017). The role of measurement uncertainty in the conformity assessment of the chemical composition of feeds. Microchemical Journal, 131, 79-91. http://dx.doi.org/10.1016/j.microc. 2016.11.014.

Molognoni, L., Valese, A. C., Lorenzetti, A., Daguer, H., \& Lindner, J. D. D. (2016). Development of a LC-MS/MS method for the simultaneous determination of sorbic acid, natamycin and tylosin in Dulce de leche. Food Chemistry, 211, 748-756. http:// dx.doi.org/10.1016/j.foodchem.2016.05.105.

Moloney, M., Clarke, L., O'Mahony, J., Gadaj, A., O'Kennedy, R., \& Danaher, M. (2012) Determination of 20 coccidiostats in egg and avian muscle tissue using ultra high performance liquid chromatography-tandem mass spectrometry. Journal of Chromatography A, 1253, 94-104. http://dx.doi.org/10.1016/j.chroma.2012.07.001.

Mortier, L., Daeseleire, E., \& Van Peteghem, C. (2005). Liquid chromatographic tandem mass spectrometric determination of five coccidiostats in poultry eggs and feed. Journal of Chromatography B, 820(2), 261-270. http://dx.doi.org/10.1016/j.jchromb. 2005.04.016.

Mortier, L., Huet, A. C., Daeseleire, E., Huyghebaert, G., Fodey, T., Elliott, C., ... Van Peteghem, C. (2005). Deposition and depletion of five anticoccidials in eggs. Journal of Agricultural and Food Chemistry, 53(18), 7142-7149. http://dx.doi.org/10.1021/ jf050836r.

Nakajima, T., Nagano, C., Sasamoto, T., Hayashi, H., Kanda, M., Kanai, S., ... Takano, I. (2012). Development and validation of rapid analysis method for multi-class veterinary drugs in livestock products by LC-MS/MS. Food Hygiene and Safety Science, 53(5), 243-253. http://dx.doi.org/10.3358/shokueishi.53.243.

O'Keeffe, M., Capurro, E., Danaher, M., Campbell, K., \& Elliott, C. T. (2007). Investigation of the causes for the occurrence of residues of the anticoccidial feed additive nicarbazin in commercial poultry. Food Additives \& Contaminants, 24(9), 923-934. http://dx.doi.org/10.1080/02652030701258778. 
Olejnik, M., Szprengier-Juszkiewicz, T., \& Jedziniak, P. (2011). Depletion study on nicarbazin and narasin in tissues and eggs of hens housed in deep litter. Bulletin of the Veterinary Institute in Pulawy, 55, 761-766.

Penz, A. M., Vieira, S. L., \& Ludtke, J. V. (1999). Residues in broiler tissue and litter. Applied Poultry Science, 8, 292-297.

Phibro (2016). Aviax Plus. (Retrieved from http://phibro.com.br/uploads/produtos/ 1441134872-Ficha Tecnica - Aviax Plus.pdf).

Pizarro, L. C. R., \& Ferreira, A. J. P. (2014). Anticoccidianos. In H. de S. Spinosa, J. Palermo-Neto, \& S. L. Górniak (Eds.), Medicamentos em animais de produção (pp. 312329). (1st ed.). Rio de Janeiro: Guanabara Koogan.

Poli-Nutri (2016). Poli-Nutri. (Retrieved from http://www.polinutri.com.br/hotsites/ produtos_detalhe.asp? id_tb_produto $=2985 \&$ id_tb_categoria $=2$ ).

Protasiuk, E., Olejnik, M., Szprengier-Juszkiewicz, T., Jedziniak, P., \& Zmudzki, J. (2015). Determination of nicarbazin in animal feed by high-performance liquid chromatography with interlaboratory evaluation. Analytical Letters, 48(14), 2183-2194. http://dx.doi.org/10.1080/00032719.2015.1025277.

Riviere, J. E., \& Papich, M. G. (2009). Veterinary pharmacology and therapeutics (9th ed.). Iowa, United States: Wiley-Blackwell.

Robert, C., Gillard, N., Brasseur, P.-Y., Pierret, G., Ralet, N., Dubois, M., \& Delahaut, P. (2013). Rapid multi-residue and multi-class qualitative screening for veterinary drugs in foods of animal origin by UHPLC-MS/MS. Food Additives \& Contaminants. Part A Chemistry, Analysis, Control, Exposure \& Risk Assessment, 30(3), 443-457. http://dx. doi.org/10.1080/19440049.2012.751632.

Rogers, E. F., Brown, R. D., Brow, J. E., Kazazis, D. M., Leanza, W. J., Nichols, J. R., .. Rodino, T. M. (1983). Nicarbazin complex yields dinitrocarbanilide as ultrafine crystals with improved anticoccidial activity. Science, 222(10), 630-632.

Roll, V. F. B., Dai Pra, M. A., \& Roll, A. P. (2011). Research on Salmonella in broiler litter reused for up to 14 consecutive flocks. Poultry Science, 90(10), 2257-2262. http://dx. doi.org/10.3382/ps.2011-01583.

SANCO (2008). Guidelines for the implementation of decision 2002/657/EC.

Shao, B., Wu, X., Zhang, J., Duan, H., Chu, X., \& Wu, Y. (2009). Development of a rapid LC-MS-MS method for multi-class determination of 14 coccidiostat residues in eggs and chicken. Chromatographia, 69(9/10), 1083-1088. http://dx.doi.org/10.1365/ s10337-009-1009-z.

Souza, S. V. C., Silva, G., Diniz, M. H. G. M., Santos, E. V., Lima, J. A., \& Teodoro, J. C. (2001). Determinaçao de nicarbazina em tecidos de origem animal. Food Science and Technology, 21(31), 34-38.

Spínosa, H. S., Palermo-Neto, J., \& Górniak, S. L. (2014). Medicamentos em Animais de Produção (1st ed.). Rio de Janeiro: Guanabara Koogan.

Stubbings, G., \& Bigwood, T. (2009). The development and validation of a multiclass liquid chromatography tandem mass spectrometry (LC-MS/MS) procedure for the determination of veterinary drug residues in animal tissue using a QuEChERS (QUick, Easy, CHeap, Effective, Rugged and Safe) approach. Analytica Chimica Acta,
637(1-2), 68-78. http://dx.doi.org/10.1016/j.aca.2009.01.029.

Tarbin, J. A., Bygrave, J., Bigwood, T., Hardy, D., Rose, M., \& Sharman, M. (2005). The effect of cooking on veterinary drug residues in food: Nicarbazin (Dinitrocarbanilide component). Food Additives and Contaminants, 22(11), 1126-1131. http://dx.doi.org/ 10.1080/02652030500357193.

Taylor, B. N. (2009). Guidelines for evaluating and expressing the uncertainty of NIST measurement results (rev. DIAN).

U.S. National Library of Medicine (2013). Toxicology data network. (Retrieved January 10, 2016, from http://chem.sis.nlm.nih.gov/chemidplus/name/nicarbazin).

USDA-FSIS (2005). National Residue Program scheduled sampling plans. (Retrieved from https://www.fsis.usda.gov/wps/wcm/connect/df2fbd58-d3f5-4527-8a4f5741d6f467ea/2005-Blue-Book.pdf?MOD = AJPERES).

USDA-FSIS (2013). United States National Residue Program for meat, poultry, and egg products. Residue sample results. (Retrieved from http://www.fsis.usda.gov/wps/wcm/ connect/0de80b0c-05d5-48f6-b494-8a361d2de0c4/2013-RedBook.pdf?MOD = AJPERES).

USDA-FSIS (2014). United States National Residue Program for meat, poultry, and egg products. FY 2014 residue sample results. (Retrieved from http://www.fsis.usda.gov/wps/ wcm/connect/2428086b-f8ec-46ed-8531-a45d10bfef6f/2014-RedBook.pdf?MOD = AJPERES).

USERS (2016). Poultry and eggs. Overview. (Retrieved from https://www.ers.usda.gov/ topics/animal-products/poultry-eggs).

Valese, A. C., Molognoni, L., Souza, N. C., Ploêncio, L. A. S., Costa, A. C. O., Barreto, F., \& Daguer, H. (2017). Development, validation and different approaches for the measurement uncertainty of a multi-class veterinary drugs residues LC-MS method for feeds. Journal of Chromatography B, 1053, 48-59. http://dx.doi.org/10.1016/j. jchromb.2017.03.026.

Verstraete, F. (2013). Risk management of undesirable substances in feed following updated risk assessments. Toxicology and Applied Pharmacology, 270(3), 230-247. http://dx.doi.org/10.1016/j.taap.2010.09.015.

Wang, X., Liu, Y., Su, Y., Yang, J., Bian, K., Wang, Z., \& He, L. M. (2014). High-throughput screening and confirmation of 22 banned veterinary drugs in feedstuffs using LC-MS/ MS and high-resolution orbitrap mass spectrometry. Journal of Agricultural and Food Chemistry, 62(2), 516-527. http://dx.doi.org/10.1021/jf404501j.

Yue, Z.-F., Kang, H.-N., Chen, X.-X., Xiao, C.-G., Hou, L.-X., Luo, Z.-J., ... Shen, J.-C (2013). Simultaneous determination of 20 coccidiostat residues in chicken by liquid chromatography-tandem mass spectrometry. Chinese Journal of Analytical Chemistry, 40(8), 1262-1266. http://dx.doi.org/10.3724/SP.J.1096.2012.10752.

Zamengo, L., Frison, G., Gregio, M., Orrù, G., \& Sciarrone, R. (2011). Determination of illicit drugs in seized materials: Role of sampling and analysis in estimation of measurement uncertainty. Forensic Science International, 208(1-3), 108-123. http:// dx.doi.org/10.1016/j.forsciint.2010.11.018. 